\title{
Yedinci Sınıf Seviye Belirleme Sınavı Matematik Sorularına İlişkin Uzman Görüşleri
}

\author{
The Views of Field Experts in Determining the Mathematic Questions for \\ Seventh Class Level Exam's
}

\section{Ceren ÇEVİK* \\ Bayram BIÇAK ${ }^{* *}$}

\begin{abstract}
Özet: Bu çalışmanın amacı, 2008 7. sınıf Seviye Belirleme Sınavı matematik sorularının üst düzey zihinsel becerileri ölçme düzeyine ve matematik kazanımları açısından üst düzey zihinsel becerilerin önem düzeyine ilişkin matematik eğitimi alan uzmanlarının görüşünü almaktır. Bu çalışmanın araştırma grubunu, Türkiye'nin çeşitli üniversitelerinde görev yapmakta olan 30 matematik eğitimi alan uzmanı oluşturmaktadır. Araştıma verileri, Çevik (2009) tarafından geliştirilen "Seviye Belirleme Sınavı 7. Sınıf Matematik Testi Üst Düzey Zihinsel Becerileri Belirleme Ölçeği” ile sağlanmıştır. Elde edilen verilerin yüzde ve frekansları hesaplanarak tablolaştırılmıştır. Araştırma sonunda yüzde ve frekans değerleri \%50 ve üzerinde olan görüşler dikkate alındığında 2008 Seviye Belirleme Sınavı matematik sorularında üst düzey zihinsel becerileri ölçen soru bulunmadığı tespit edilmiştir. Ayrıca matematik eğitimi alan uzmanlarının ilgili üst düzey zihinsel becerilere matematik kazanımları açısından verdikleri önem düzeyi oldukça fazladır. Alan uzmanlarının görüşleri dikkate alınarak öğrenciler için hayati önem taşıyan sınavlarda yer alan 7. sınıf matematik soruların yapılandırılmasında üst düzey düşünmenin kapılarını açma ön plana alınmalıdır. Ülkemizde yapılan ulusal sınavlardaki testlerde yer alan soruların bilişsel alanın her düzeyini ölçer nitelikte olması gerekir.
\end{abstract}

Anahtar sözcükler: Üst düzey zihinsel beceri, Seviye Belirleme Sınavı (SBS), matematik alan uzmanı

\begin{abstract}
The purpose of this study was to determine the level achieved in measuring the higher order thinking skills in 2008 seventh grade mathematic questions and the level of importance given to these higher order thinking skills, according to the views of field experts. The research group for this study consisted of 30 mathematics education experts at various universities in Turkey. Research data was provided via the "SBS exam seventh grade Identifying Higher Order Thinking Skills of Mathematics Scale" developed by Çevik (2009). The data was obtained by calculating the percentage and frequency integrated table. As a result of this research, examined by taking the percentage and frequency values of opinions above $50 \%$ into consideration, it was found that the mathematic questions in the 2008 SBS exam do not contain questions that measure higher order thinking skills. Also, the level of importance given to higher order thinking skills by experts in terms of $7^{\text {th }}$ grade math acqusitions is very high. In structuring the questions for exams, carrying vital importance for students, opening the door to higher order thinking must be brought into the foreground.
\end{abstract}

Keywords: Higher order thinking skills, Class Level Determining Exam (SBS), math academicians

\footnotetext{
* Arş. Gör., Bayburt Üniversitesi, Eğitim Fakültesi, İlköğretim Bölümü, Bayburt, cerencevik@bayburt.edu.tr

** Yrd. Doç. Dr., Akdeniz Üniversitesi, Eğitim Fakültesi, Eğitim Bilimleri Böl., Antalya, bayrambicak@yahoo.com Çevik, C., Abant İzzet Baysal Üni., Sosyal Bilimler Enstitüsü, Yüksek Lisans Tezinin gözden geçirilmiş bir bölümüdür.
} 


\section{GİRIŞ̧}

Eğitim sistemimizde temel amaç, öğrencilerimize mevcut bilgileri aktarmaktan çok, bilgiye ulaşma, bilgiyi elde etme ve kullanma becerilerini kazandırmak olmalıdır. Bu ise üst düzey zihinsel becerilerle olur (D’Agostino, 2000; Berberoğlu, Kaptan, \& Kutlu, 2002).

Alt ve üst düzey zihinsel becerileri gerektiren sorular en yaygın şekliyle Bloom ve arkadaşları tarafından geliştirilen sınıflandırmaya göre ele alınmıştır. Bu sınıflandırmada alt düzey zihinsel becerileri bilgi, kavrama ve uygulama basamakları ile üst düzey zihinsel becerileri ise; analiz, sentez ve değerlendirme basamakları ile ifade edilmiştir (Ralph, 1999; Sönmez, 2001; Koray, \& Yaman, 2002; Şahinel, 2002; Demirel, 2005). Ancak Bloom'un sınıflamasına alternatif olarak geliştirilen yeni sınıflamalar incelendiğinde Bloom'un sınıflamasındaki temel düşünce ve anlayışın çok fazla değişmediği genellikle bazı basamakların isimlerinde veya basamakların sıralamasında değişiklikler yapıldığı görülmektedir. İleri sürülen alternatif sınıflamalar tek boyutlu (Gerlach, \& Sullivan, Hannah, \& Michaelis, Gagné, \& Briggs, Stahl, \& Murphy, Quellmalz, Hauenstein, \& Haladayna) ve çok boyutlu (Tuckman, Marzano, Romizowski, Anderson, \& Krathwohl, DeBlock, Williams, \& Haladayna) olmak üzere iki grupta toplanmaktadır. Son yıllarda geliştirilen sınıflamalar iki boyutludur. Bu sınıflamalarda bilgiye ayrı bir önem verilmiş, bilişsel alan; içerik ve süreç olmak üzere iki boyuta ayrılarak incelenmiştir. Sonuç olarak, alternatif sınıflamalar Bloom'un sınıflamasını temel almış ve bu sınıflamada eksik gördükleri yanları gidermeye çalışmışlardır (Akt. Yüksel, 2007).

Üst düzey zihinsel beceriler, gelişmesi uzun zaman alan ve bireylerin yaşamda başarılı olabilmesi için kazanmış olmaları gereken yeteneklerdir. Üst düzey zihinsel becerileri gelişmiş bireyler, öğrenmiş olduğu bilgileri gerçek yaşama aktarabilmekte ve karşılaştığı sorunları çözmede bu bilgileri etkili biçimde kullanabilmektedir. Bu bağlamda eğitim etkinliklerinde öğrencilerin üst düzey zihinsel becerilerinin geliştirilmesine olanak sağlayacak öğretim yöntem ve tekniklerinin ve buna bağlı olarak da bu becerileri ölçen ve değerlendiren yaklaşımların kullanılması gerekmektedir. Bundan dolayı, öğrencilerin bu davranışları ne ölçüde kazandıklarının belirlenmesi de büyük önem taşır.

İlköğretim 6 - 8. sinıflarda yer alan öğrencilerin orta öğrenimlerini kendi düzeylerine uygun bir ortaöğretim kurumunda devam etmelerinin ön koşulunun SBS olduğu düşünülürse, bu sınavdaki soruların bilişsel seviyeleri ile okul yaşantılarındaki sınavlarda sorulan soruların bilişsel seviyeleri arasında bir paralellik olması gerektiği düşünülebilir. Böyle olmadığı takdirde, ilköğretimi başarı ile bitiren ve ortaöğretime kendi seviyesine en uygun bir ortaöğretim kurumuna yerleştirilmek isteyen öğrenciler seviye belirleme sınavında, ilköğretimde eriştikleri bilişsel seviyeye kadar olan soruları cevaplayabilecekler, seviyelerinin üzerindeki soruları cevaplayamayacaklar ve yüksek puan alma şansını kaybedeceklerdir. Ayrıca, ilköğretimi ve ortaöğretimi başarıyla bitiren ve daha sonra öğrenci seçme sınavına giren binlerce öğrencinin matematik sorularının birçoğunu yanıtlayamadığı ve test ağırlık katsayısı yüksek olması sebebiyle binlerce öğrencinin başarısız olduğu düşünüldüğünde, ilköğretim seviyesinde değerlendirme amacıyla uygulanan SBS'de sorulan matematik sorularının bilişsel yönden ne düzeyde olduğu sorusu akla gelmektedir.

\section{1. Üst Düzey Zihinsel Beceriler}

Bloom (1956)'a göre üst düzeyde düşünebilme, bilgi, hatırlama, anlama ve uygulama gibi temel düşünme becerilerinin kullanımını gerektirir; ancak analiz, sentez ve değerlendirme üst düzeyde düşünmenin bilişsel gereklilikleridir. Günümüzde yapılan çalışmalarda üst düzey düşünme becerilerinin yerini genel olarak aşağıdaki beceriler almaktadır. 
1) Problem Çözme: Daha önceden görülmemiş, yeni bir probleme uygun bir çözüm bulma sürecidir. Problem çözme karmaşık bir süreçtir. Anlama, eleştirel düşünme gibi zihinsel becerileri de kapsar.

2) Analiz: Bütünü oluşturan öğelerin bir araya getirilme, düzenleme kurallarını ortaya çıkarma gibi davranışların gösterilmesi beklenmektedir (Turgut, 1986; Özçelik, 1998; Tan, \& Erdoğan, 2004; Tekin, 2008).

3) Sentez: Sentez basamağında bireyin yeni ve özgün ürünler vermesi beklenmektedir. Bireylerden eşsiz ve benzersiz bir ürün ortaya koymaları istenir. Öğrencinin ortaya koyduğu ürünün daha önce karşıllaştıklarına, bildiklerine benzememesi gereklidir. Bu aşamada parçadan bütüne ulaşma davranışları ağırlık kazanmaktadır (Özçelik, 1992; Turgut, 1992; Tekin, 1993; Tan, \& Erdoğan, 2004).

4) Değerlendirme: Değerlendirme basamağı Bloom'un taksonomisinde en üst düzeydeki bilişsel becerileri kapsamaktadır. Son yıllarda yapılan taksonomi revizyonlarında değerlendirmeye, sentez yani yaratma basamağından önce yer verilmiş, yani daha alt basamakta davranışlar olarak sınıflandırılmışırı (Krathwohl, 2002).

5) Eleştirel Düşünme: Eleştirel düşünme, temelde bilgiyi etkili bir biçimde elde etme, değerlendirme, kullanma yeteneği ve eğilimine dayanır.

6) Yaratıcı Düşünme: Yaratıcılık; yeni, orijinal ve hayal gücüne dayalı şekilde düşünme ya da bu şekilde bir şeyler yapma sürecidir.

Özellikle Bloom ve Haladyn'ın yapmış olduğu sınıflamalarda bu becerilere rastlanmaktadır. Diğer Williams (1977), Hannah, \& Michaelis (1977), Gagne, \& Briggs (1979), Quellmalz (1987), Hauenstein (1998), Anderson, \& Krathwohl (2001)'un sınıflamalarında yer alan basamaklarda da bu beceriler kısmen görülebilmektedir (Akt. Yüksel, 2007).

\subsection{Sinıf Seviye Belirleme Sınavı'nda Yer Alan Matematik Sorularının Analizi}

7. sınıf SBS matematik sorularının matematik programında yer alan konularla ilişkilendirilerek oluşturulan analizi aşağıda Tablo 1'de verilmiştir.

Tablo 1. İlköğretim 7 SBS Matematik Sorularının Analizi.

\begin{tabular}{|l|l|}
\hline Konular & $\mathbf{2 0 0 8}$ \\
\hline Tam Sayılarla Çarpma İşlemi & 1 \\
\hline Tam Sayılarla Bölme İşlemi & - \\
\hline Rasyonel Sayıları Tanıyalım & 1 \\
\hline Düzlemdeki Doğrular & 2 \\
\hline Cebirsel İfadeleri Çarpma & 1 \\
\hline Doğru Orantı & 1 \\
\hline Çokgenlerin Eşliği ve Benzerliği & 1 \\
\hline Hayatımızdaki Grafikler & 2 \\
\hline Rasyonel Sayılarla Adım Adım İşlemler & 1 \\
\hline Rasyonel Sayı Problemleri & - \\
\hline Doğrusal Denklemler ve Grafiği & 1 \\
\hline Olasılığın Geometriyle İlişkisi & 1 \\
\hline İçi Çokgen Dolu & 1 \\
\hline
\end{tabular}




\begin{tabular}{|l|c|}
\hline Üslü Nicelikler & - \\
\hline Örüntüler ve İlişkiler & 1 \\
\hline Yüzde Problemleri & 1 \\
\hline Kenar Alan Çevre Ayrılmazlığı & 1 \\
\hline Çember ve Daire & 1 \\
\hline Dik Dairesel Silindirin Alanı ve Hacmi & 1 \\
\hline Toplam & 18 \\
\hline
\end{tabular}

Tablo 1'de görüldüğü gibi 2008 SBS Matematik testinde “Tam Sayılarda Bölme İşlemi, Rasyonel Sayı Problemleri ve Üslü Nicelikler” dışında diğer konulardan en az bir soru yer almaktadır.

\subsection{Araştırmanın Amacı}

Bu çalışmanın amacı, 2008 7. sınıf Seviye Belirleme Sınavı matematik sorularının üst düzey zihinsel becerileri ölçme düzeyine ilişkin ve matematik kazanımları açısından üst düzey zihinsel becerilerin önem düzeyine ilişkin matematik eğitimi alan uzmanlarının görüşünü almaktır. Bu amacı gerçekleştirmek için aşağıdaki sorulara cevap aranacaktır:

- Alan uzmanlarının 2008 SBS 7. sınıf matematik sorularının üst düzey zihinsel becerileri ölçme düzeyine dönük görüşleri nelerdir?

- Alan uzmanlarının matematik kazanımları açısından üst düzey zihinsel becerilere atfettikleri önem düzeyi nedir?

\section{YÖNTEM}

\section{1. Çalışmanın Modeli}

Bu araştırma, 2008 yılı ilköğretim 7. sınıf öğrencilerine uygulanan seviye belirleme sınavı matematik sorularının üst düzey zihinsel becerileri ölçme düzeyine ve matematik kazanımları açısından üst düzey zihinsel becerilerin önem düzeyine ilişkin alan uzmanlarının görüşlerini belirlemeye yönelik betimsel bir araştırmadır.

\subsection{Araştırma Grubu}

Üniversitelerde görev yapmakta olan 36 matematik eğitimi alan uzmanından 30'u, çalışmada kullanılan ölçeği geri vermiş veya elektronik posta ile göndermiştir. Geri dönen ölçeklerden, yanlış ve eksik doldurulmuş olan 6 ölçek değerlendirme dışı bırakılmıştır.

Geriye kalan kişilere ait demografik bilgiler aşağıda Tablo 2 (Matematik Eğitimi Alan Uzmanlarının Cinsiyet, Görev Yaptıkları Bölüm, Öğrenim Durumu, Mezun Olunan Fakülte Türü, Hizmet Süresi Değişkenlerine Göre Dağılımı)'de verilmiştir.

Tablo 2. Matematik Eğitimi Alan Uzmanlarının Cinsiyet, Görev Yaptıkları Bölüm, Öğrenim Durumu, Mezun Olunan Fakülte Türü, Hizmet Süresi Değişkenlerine Göre Dağılımı

\begin{tabular}{|l|l|c|c|c|c|c|c|}
\hline \multirow{2}{*}{ Değişkenler } & \multicolumn{2}{|c|}{ Erkek } & \multicolumn{2}{|c|}{ Kadın } & \multicolumn{2}{c|}{ Toplam } \\
\cline { 3 - 9 } \multicolumn{2}{|c|}{} & $\mathbf{N}$ & $\mathbf{\%}$ & $\mathbf{N}$ & $\mathbf{\%}$ & $\mathbf{N}$ & $\mathbf{\%}$ \\
\hline \multirow{2}{*}{ Görev yaptıkları bölüm } & İlköğretim & 13 & 43,3 & 11 & 36,7 & 24 & 80 \\
\cline { 2 - 9 } & Ortaöğretim & 5 & 16,7 & 1 & 3,3 & 6 & 20 \\
\hline
\end{tabular}




\begin{tabular}{|l|l|c|c|c|c|c|c|}
\hline \multirow{4}{*}{ Mezun olunan fakülte türü } & Eğitim Fak. & 14 & 46,7 & 10 & 23,3 & 24 & 80,0 \\
\cline { 2 - 8 } & Eğitim Enst. & 0 & 0,0 & 2 & 6,7 & 2 & 6,7 \\
\cline { 2 - 8 } & Fen Edebiyat Fak. & 4 & 13,3 & 0 & 0,0 & 4 & 13,3 \\
\hline \multirow{5}{*}{ Öğrenim durumu } & Lisans & 1 & 3,3 & 0 & 0,0 & 1 & 3,3 \\
\cline { 2 - 8 } & Yüksek lisans yapıyor & 1 & 3,3 & 8 & 26,7 & 9 & 30,0 \\
\cline { 2 - 8 } & Yüksek lisansı bitirmiş & 0 & 0,0 & 1 & 3,3 & 1 & 3,3 \\
\cline { 2 - 8 } & Doktora yapıyor & 6 & 20 & 2 & 6,7 & 8 & 26,7 \\
\cline { 2 - 8 } & Doktorasını bitirmiş & 10 & 33,4 & 1 & 3,3 & 11 & 36,7 \\
\hline \multirow{5}{*}{ Hizmet süresi } & $0-4$ yll & 6 & 20,0 & 11 & 36,7 & 17 & 56,7 \\
\cline { 2 - 8 } & 5-9 yll & 2 & 6,7 & 0 & 0,0 & 2 & 6,7 \\
\cline { 2 - 8 } & $10-14$ yll & 7 & 23,3 & 1 & 3,3 & 8 & 26,6 \\
\cline { 2 - 8 } & 15 yıl ve üzeri & 3 & 10,0 & 0 & 0,0 & 3 & 10,0 \\
\hline \multirow{4}{*}{ Toplam } & & 18 & 60 & 12 & 40 & 30 & 100 \\
\hline
\end{tabular}

Tablo 2'de görüldüğü gibi, alan uzmanlarının \%60’ı erkek, \%40’ı kadındır. Görev yaptıkları bölüme göre \%80’i ilköğretim, \%20'si ortaöğretimde çalışmalarını sürdürdüğü görülmektedir. Mezun oldukları fakülte türüne göre \%80'i eğitim fakültesi, \%6,7'si eğitim enstitüsü, \%13,3'ü fen-edebiyat fakültesi mezunudur. Öğrenim durumları incelendiğinde, \%3,3'ünün lisans mezunu olduğu, \%30’unun yüksek lisans yapıyor olduğu, \%3,3’ünün yüksek lisansını bitirdiğí, \%26,7'sinin doktorasını yapıyor olduğu, \%36,7'sinin doktorasını bitirdiği görülmektedir. Hizmet süreleri incelendiğinde, alan uzmanlarının \%56,7'sinin 0-4 yıl arasında değişen, \%6,7'sinin 5-9 yıl arasında değișen, \%26,6'sının 10-14 yıl arasında değișen, \%10'unun 15 yıl ve üzeri hizmet sürelerine sahip olduğu görülmektedir.

\subsection{Veri Toplama Aracı}

Çevik (2009) tarafından geliştirilen ölçme aracı (SBS 7. sınıf Matematik Testi Üst Düzey Zihinsel Becerileri Belirleme Ölçeği) yardımıyla üç tür veri grubu kullanılmıştır. Belirtilen ölçek, kişisel bilgi formu ve bu araçlarla birlikte sunulan 2008 yılı SBS 7. sınıf matematik testi sorularının matematik kazanımlarıyla ilişkilendirilmiş analiz tabloları.

\subsection{Verilerin Toplanması ve Analizi}

Çalışmaya katılan matematik eğitimi alan uzmanlarına SBS 7. sınıf matematik testi üst düzey zihinsel becerileri belirleme ölçeği uygulanmıştır. Alan uzmanlarının bir kısmına birebir görüşülerek gönüllülük esasına dayalı olarak bir kısmına ise elektronik posta ile ulaşılmış yine gönüllülük esas alınmıştır.

Araştırma sonucunda toplanan veriler bir istatistik paket programı kullanılarak analiz edilmiştir. Araştırma grubundaki alan uzmanlarının ölçekte yer alan üst düzey zihinsel beceriyi ölçen soruya ilişkin ve ilgili becerinin matematik kazanımlar açısından önem düzeyine verdikleri tepkilere ait frekans ve yüzdeler hesaplanmış, grubun \%50 ve üzeri çoğunluğu üzerinden değerlendirilmiştir. 


\section{BULGULAR}

\subsection{Birinci Araştırma Sorusuna Ait Bulgular}

- Alan uzmanlarının 2008 SBS 7. sınıf matematik sorularının üst düzey zihinsel becerileri ölçme düzeyine dönük görüşleri nelerdir?

Alan uzmanlarının SBS matematik sorularının üst düzey zihinsel becerileri ölçme düzeyine dönük görüşleri incelendiğinde en yüksek frekanslı olan sorularla ilişkilendirilerek sırasıyla Tablo 3’te yer verilmiştir.

Tablo 3. Matematik Eğitimi Alan Uzmanlarının Becerilere Verdikleri En Yüksek Oranlı Frekans ve Yüzdeler

\begin{tabular}{|c|c|c|c|c|c|c|c|}
\hline \multicolumn{4}{|c|}{ Alan Uzmanı } & \multicolumn{4}{|c|}{ Alan Uzmanı } \\
\hline Beceri No: & $\begin{array}{l}\text { İlgili beceriyi } \\
\text { ölçen madde } \\
\text { var mı? } \\
\text { Varsa Madde } \\
\text { (ler) No: }\end{array}$ & $\mathrm{n}$ & $\%$ & Beceri No: & \begin{tabular}{|c|} 
İlgili beceriyi \\
ölçen madde \\
var mı? Varsa \\
Madde (ler) \\
No:
\end{tabular} & $\mathrm{n}$ & $\%$ \\
\hline \multicolumn{4}{|c|}{ Problem Çözme } & \multicolumn{4}{|c|}{ Değerlendirme } \\
\hline 1 & s7 & 6 & 20,0 & 19 & s16 & 9 & 30,0 \\
\hline 2 & s1 & 9 & 30,0 & 20 & s4, 16-17 & 4 & 13,3 \\
\hline 3 & s15 & 6 & 20,0 & 21 & s6, 16 & 4 & 13,3 \\
\hline 4 & s7 & 7 & 23,3 & 22 & s7 & 4 & 13,3 \\
\hline 5 & s7, 13 & 5 & 16,7 & 23 & s16 & 4 & 13,3 \\
\hline 6 & s15 & 4 & 13,3 & 24 & s11, 16 & 3 & 10,0 \\
\hline 7 & s5, 14 & 4 & 13,3 & 25 & s1 & 3 & 10,0 \\
\hline 8 & s3 & 11 & 36,7 & \multirow{2}{*}{\multicolumn{4}{|c|}{ Eleştirel Düşünme }} \\
\hline \multicolumn{4}{|l|}{ Analiz } & & & & \\
\hline 9 & $\mathrm{~s} 1$ & 5 & 16,7 & 26 & s7 & 8 & 26,7 \\
\hline 10 & s14, 16 & 5 & 16,7 & 27 & s7, 11 & 4 & 13,3 \\
\hline 11 & s7, 16 & 8 & 26,7 & 28 & s13 & 11 & 36,7 \\
\hline 12 & s3 & 8 & 26,7 & 29 & s2, 5, 8 & 3 & 10,0 \\
\hline 13 & s6, 10, 16 & 3 & 10,0 & 30 & s17 & 4 & 13,3 \\
\hline \multirow{3}{*}{\multicolumn{4}{|c|}{ Sentez }} & 31 & s5, 11-12 & 5 & 16,7 \\
\hline & & & & 32 & s11 & 2 & 6,7 \\
\hline & & & & \multicolumn{4}{|c|}{ Yaratıcı Düşünme } \\
\hline 14 & s17 & 14 & 46,7 & 33 & s10 & 6 & 20,0 \\
\hline 15 & s17 & 8 & 26,7 & 34 & s9 & 7 & 23,3 \\
\hline 16 & s17 & 7 & 23,3 & 35 & s10-13 & 3 & 10,0 \\
\hline 17 & s17 & 5 & 16,7 & 36 & s7, 12 & 2 & 6,7 \\
\hline \multirow[t]{2}{*}{18} & s17 & 4 & 13,3 & 37 & $\mathrm{~s} 10$ & 3 & 10,0 \\
\hline & & & & 38 & s18 & 2 & 6,7 \\
\hline \multicolumn{2}{|l|}{ (s: soru) } & & & 39 & s17-18 & 5 & 16,7 \\
\hline
\end{tabular}

Tablo 3’te görüldüğü gibi alan uzmanlarının; problem çözme, analiz, sentez, değerlendirme, eleştirel düşünme, yaratıcı düşünme düzeylerine ilişkin matematik testinde ilgili becerileri ölçen 
soru bulunup bulunmadığına ilişkin görüşleri incelendiğinde \%50 ve üzerinde hemfikir oldukları soru bulunmadığı saptanmıştır.

\section{2. İkinci Araştırma Sorusuna Ait Bulgular}

- Alan uzmanlarının matematik kazanımları açısından üst düzey zihinsel becerilere atfettikleri önem düzeyi nedir?

Alan uzmanlarının, matematik kazanımları açısından ölçekte yer alan üst düzey zihinsel becerilere verdikleri önem düzeylerine ait ortanca ve tepe değerleri Tablo 4'te verilmiştir.

Tablo 4. Alan Uzmanlarının Üst Düzey Zihinsel Becerilere Matematik Kazanımları Açısından Verdikleri Önem Düzeylerine Ait Ortanca ve Tepe Değerleri

\begin{tabular}{|c|c|c|c|c|c|c|c|c|}
\hline $\begin{array}{c}\text { Beceri } \\
\text { No }\end{array}$ & Ortanca & $\begin{array}{c}\text { Tepe } \\
\text { Değer }\end{array}$ & $\begin{array}{c}\text { Beceri } \\
\text { No }\end{array}$ & Ortanca & $\begin{array}{c}\text { Tepe } \\
\text { Değer }\end{array}$ & $\begin{array}{c}\text { Beceri } \\
\text { No }\end{array}$ & Ortanca & $\begin{array}{c}\text { Tepe } \\
\text { Değer }\end{array}$ \\
\hline $\mathbf{1}$ & 4,5 & 5 & $\mathbf{1 4}$ & 4 & 5 & $\mathbf{2 7}$ & 5 & 5 \\
\hline $\mathbf{2}$ & 4 & 5 & $\mathbf{1 5}$ & 5 & 5 & $\mathbf{2 8}$ & 5 & 5 \\
\hline $\mathbf{3}$ & 4 & 5 & $\mathbf{1 6}$ & 4,5 & 5 & $\mathbf{2 9}$ & 5 & 5 \\
\hline $\mathbf{4}$ & 5 & 5 & $\mathbf{1 7}$ & 4 & 5 & $\mathbf{3 0}$ & 5 & 5 \\
\hline $\mathbf{5}$ & 4 & 4 & $\mathbf{1 8}$ & 4 & 5 & $\mathbf{3 1}$ & 5 & 5 \\
\hline $\mathbf{6}$ & 5 & 5 & $\mathbf{1 9}$ & 4 & 4 & $\mathbf{3 2}$ & 4 & 5 \\
\hline $\mathbf{7}$ & 5 & 5 & $\mathbf{2 0}$ & 4 & 5 & $\mathbf{3 3}$ & 5 & 5 \\
\hline $\mathbf{8}$ & 4 & 5 & $\mathbf{2 1}$ & 5 & 5 & $\mathbf{3 4}$ & 4 & 5 \\
\hline $\mathbf{9}$ & 5 & 5 & $\mathbf{2 2}$ & 4 & 5 & $\mathbf{3 5}$ & 4 & 5 \\
\hline $\mathbf{1 0}$ & 4 & 4 & $\mathbf{2 3}$ & 4 & 5 & $\mathbf{3 6}$ & 4 & 5 \\
\hline $\mathbf{1 1}$ & 5 & 5 & $\mathbf{2 4}$ & 4 & 5 & $\mathbf{3 7}$ & 5 & 5 \\
\hline $\mathbf{1 2}$ & 4 & 5 & $\mathbf{2 5}$ & 4 & 5 & $\mathbf{3 8}$ & 4 & 5 \\
\hline $\mathbf{1 3}$ & 4 & 5 & $\mathbf{2 6}$ & 4 & 5 & $\mathbf{3 9}$ & 5 & 5 \\
\hline
\end{tabular}

Tablo 4'teki ortanca ve tepe değerleri incelendiğinde, matematik alan uzmanlarının, matematik kazanımları açısından ölçekte yer alan becerilerin önem düzeyinin "çok önemli" seçeneğinde yoğunlaştı̆̆ı görülmektedir. Genel olarak değerlendirildiğinde, alan uzmanları bu becerileri "çok önemli” bulduklarını belirtmişlerdir.

Matematik Alan uzmanlarının, 7. sınıf matematik kazanımlarını açısından üst düzey zihinsel becerilere verdikleri önem düzeylerine ait yüzde ve frekans değerleri, ilgili alt becerilere göre gruplandırılarak açıklanmıştır.

Alan uzmanlarının, matematik kazanımları açısından problem çözme becerilerine verdikleri önem düzeylerine ait frekans ve yüzde değerleri Tablo 5’te verilmiştir. 
Tablo 5. Alan Uzmanlarının Problem Çözme Becerilerine Matematik Kazanımları Açısından Verdikleri Önem Düzeylerine Ait Frekans ve Yüzde Değerleri

\begin{tabular}{|l|l|c|c|c|c|c|}
\hline \multirow{2}{*}{\multicolumn{2}{|l}{ Beceriler }} & \multicolumn{2}{l}{ Önem Düzeyi } \\
\cline { 3 - 7 } & & $\begin{array}{c}\text { Çok } \\
\text { Önemsiz }\end{array}$ & Önemsiz & $\begin{array}{c}\text { Orta Düzeyde } \\
\text { Önemli }\end{array}$ & Önemli & $\begin{array}{c}\text { Çok } \\
\text { Önemli }\end{array}$ \\
\hline \multirow{2}{*}{ 1. Problemi açıklama ve tanımlama } & $\mathrm{f}$ & 0 & 1 & 2 & 12 & 15 \\
& $\%$ & 0,0 & 3,3 & 6,7 & 40,0 & 50,0 \\
\hline \multirow{2}{*}{ 2. İlgili bilgiyi seçme } & $\mathrm{f}$ & 0 & 1 & 3 & 12 & 13 \\
& $\%$ & 0,0 & 3,3 & 10,0 & 40,0 & 43,3 \\
\hline 3. Çözüm yollarını belirleme ve & $\mathrm{f}$ & 0 & 0 & 3 & 13 & 14 \\
seçme & $\%$ & 0,0 & 0,0 & 10,0 & 43,3 & 46,7 \\
\hline 4. Sonuç çıkarma. & $\mathrm{f}$ & 0 & 1 & 6 & 6 & 16 \\
& $\%$ & 0,0 & 3,3 & 20,0 & 20,0 & 53,3 \\
\hline 5. Konuyu veya problemi & $\mathrm{f}$ & 0 & 1 & 3 & 12 & 12 \\
belirlemesi & $\%$ & 0,0 & 3,3 & 10,0 & 40,0 & 40,0 \\
\hline 6. Temel varsayımların farkına & $\mathrm{f}$ & 0 & 2 & 4 & 7 & 14 \\
varabilmesi & $\%$ & 0,0 & 6,7 & 13,3 & 23,3 & 46,7 \\
\hline 7. Kavramlaştırma becerisi. & $\mathrm{f}$ & 0 & 0 & 6 & 8 & 15 \\
& $\%$ & 0,0 & 0,0 & 20,0 & 26,7 & 50,0 \\
\hline 8. Kesin sonuca karar verebilme & $\mathrm{f}$ & 0 & 2 & 10 & 7 & 11 \\
becerisi & $\%$ & 0,0 & 6,7 & 33,3 & 23,3 & 36,7 \\
\hline
\end{tabular}

Tablo 5’te yer alan problem çözme becerilerinin tamamının alan uzmanları tarafından çok önemli görüldüğg̈ü saptanmıştır.

Alan uzmanlarının, matematik kazanımları açısından analiz düzeyi becerilerine verdikleri önem düzeylerine ait frekans ve yüzde değerleri Tablo 6'da verilmiştir.

Tablo 6. Alan Uzmanlarının Analiz Düzeyi Becerilerine Matematik Kazanımları Açısından Verdikleri Önem Düzeylerine Ait Frekans ve Yüzde Değerleri

\begin{tabular}{|l|l|c|c|c|c|c|}
\hline \multirow{2}{*}{ Beceriler } & \multicolumn{2}{|l|}{ Önem Düzeyi } \\
\cline { 3 - 8 } & & $\begin{array}{c}\text { Çok } \\
\text { Önemsiz }\end{array}$ & Önemsiz & $\begin{array}{c}\text { Orta Düzeyde } \\
\text { Önemli }\end{array}$ & Önemli & $\begin{array}{l}\text { Çok } \\
\text { Önemli }\end{array}$ \\
\hline $\begin{array}{l}\text { 9. Verilen bir bütününün parçaları } \\
\text { arasındaki ilişkileri belirleme }\end{array}$ & $\mathrm{f}$ & 0 & 1 & 2 & 9 & 17 \\
& $\%$ & 0,0 & 3,3 & 6,7 & 30,0 & 56,7 \\
\hline $\begin{array}{l}\text { 10. Elde edilen verileri } \\
\text { sinıflandırabilme }\end{array}$ & $\mathrm{f}$ & 0 & 0 & 5 & 14 & 9 \\
\hline $\begin{array}{l}\text { 11. Verilenlerden yola çıkarak bir } \\
\text { veya birden fazla özelliğe göre } \\
\text { karşllaştırmalar yapar }\end{array}$ & $\mathrm{f}$ & 0,0 & 0,0 & 16,7 & 46,7 & 30,0 \\
\hline $\begin{array}{l}\text { 12. Soruda bilinmeyenin hangi } \\
\text { ilkelere göre kurulduğunu ve } \\
\text { işlediğini ortaya koyabilme }\end{array}$ & $\mathrm{f}$ & 0,0 & 1 & 4 & 8 & 16 \\
\hline $\begin{array}{l}\text { 13. Bir bilgi bütününü örgütleme } \\
\text { ilkelerine göre ayrıştırabilme. }\end{array}$ & $\mathrm{f}$ & 1 & 0 & 8 & 10 & 11 \\
\hline & $\%$ & 3,3 & 0,0 & 26,7 & 33,3 & 36,7 \\
\hline
\end{tabular}


9., 11., 12. ve 13. becerilerin alan uzmanları tarafından çok önemli görüldüğü; 10. becerinin ise önemli görüldüğü saptanmıştır.

Alan uzmanlarının, matematik kazanımları açısından sentez düzeyi becerilerine verdikleri önem düzeylerine ait frekans ve yüzde değerleri Tablo 7'de verilmiştir.

Tablo 7. Alan Uzmanlarının Sentez Düzeyi Becerilerine Matematik Kazanımları Açısından Verdikleri Önem Düzeylerine Ait Frekans ve Yüzde Değerleri

\begin{tabular}{|c|c|c|c|c|c|c|}
\hline \multirow{2}{*}{ Beceriler } & & \multicolumn{5}{|c|}{ Önem Düzeyi } \\
\hline & & \multirow{3}{*}{$\begin{array}{c}\begin{array}{c}\text { Çok } \\
\text { Önemsiz }\end{array} \\
0 \\
0,0\end{array}$} & \multirow{3}{*}{$\begin{array}{c}\text { Önemsiz } \\
0 \\
0,0\end{array}$} & \multirow{3}{*}{$\begin{array}{c}\begin{array}{c}\text { Orta Düzeyde } \\
\text { Önemli }\end{array} \\
8 \\
26,7\end{array}$} & \multirow{3}{*}{$\begin{array}{c}\text { Önemli } \\
9 \\
30,0\end{array}$} & \multirow{2}{*}{$\begin{array}{c}\begin{array}{c}\text { Çok } \\
\text { Önemli }\end{array} \\
13\end{array}$} \\
\hline 14 Örïntï olusturma & $\mathrm{f}$ & & & & & \\
\hline 14. Uruntu oluşurma & $\%$ & & & & & 43,3 \\
\hline \multirow{2}{*}{$\begin{array}{l}\text { 15. İşlenen verilerle yeni bir } \\
\text { model oluşturma }\end{array}$} & $\mathrm{f}$ & 0 & 0 & 7 & 6 & 15 \\
\hline & $\%$ & 0,0 & 0,0 & 23,3 & 20,0 & 50,0 \\
\hline \multirow{2}{*}{$\begin{array}{l}\text { 16. Soyut bir ilişkiler takımı } \\
\text { geliştirme }\end{array}$} & $\mathrm{f}$ & 0 & 0 & 7 & 8 & 15 \\
\hline & $\%$ & 0,0 & 0,0 & 23,3 & 26,7 & 50,0 \\
\hline \multirow{2}{*}{$\begin{array}{l}\text { 17. Elde edilen verileri derleyip } \\
\text { işleyerek yeni bir biçim geliştirme }\end{array}$} & $\mathrm{f}$ & 1 & 0 & 4 & 10 & 14 \\
\hline & $\%$ & 3,3 & 0,0 & 13,3 & 33,3 & 46,7 \\
\hline \multirow{2}{*}{$\begin{array}{l}\text { 18. Elde edilen bulgulardan yeni } \\
\text { bir desen oluşturma }\end{array}$} & $\mathrm{f}$ & 1 & 0 & 6 & 9 & 12 \\
\hline & $\%$ & 3,3 & 0,0 & 20,0 & 30,0 & 40,0 \\
\hline
\end{tabular}

Alan uzmanları tarafından Tablo 7’de yer alan sentez düzeyi becerilerinin çok önemli görüldüğü saptanmıştır.

Alan uzmanlarının, matematik kazanımları açısından değerlendirme düzeyi becerilerine verdikleri önem düzeylerine ait frekans ve yüzde değerleri Tablo 8’de verilmiştir.

Tablo 8. Alan Uzmanlarının Değerlendirme Düzeyi Becerilerine Matematik Kazanımları Açısından Verdikleri Önem Düzeylerine Ait Frekans ve Yüzde Değerleri

\begin{tabular}{|l|l|c|c|c|c|c|}
\hline \multirow{2}{*}{ Beceriler } & \multicolumn{3}{|l|}{ Önem Düzeyi } \\
\cline { 3 - 7 } & $\begin{array}{c}\text { Çok } \\
\text { Önemsiz }\end{array}$ & Önemsiz & $\begin{array}{c}\text { Orta Düzeyde } \\
\text { Önemli }\end{array}$ & $\begin{array}{c}\text { Önem } \\
\text { li }\end{array}$ & $\begin{array}{c}\text { Çok } \\
\text { Önemli }\end{array}$ \\
\hline 19. Verilen bir modeli yorumlama & $\mathrm{f}$ & 0 & 1 & 2 & 13 & 12 \\
& $\%$ & 0,0 & 3,3 & 6,7 & 43,3 & 40,0 \\
\hline $\begin{array}{l}\text { 20. İşlenen verileri ve oluşturulan } \\
\text { modeli yorumlama }\end{array}$ & $\mathrm{f}$ & 0 & 1 & 5 & 10 & 13 \\
\hline $\begin{array}{l}\text { 21. Elde edilen verilere göre bir } \\
\text { karara varabilme }\end{array}$ & $\mathrm{f}$ & 0,0 & 3,3 & 16,7 & 33,3 & 43,3 \\
\hline $\begin{array}{l}\text { 22. Bir gerekçeden mantıklı bir } \\
\text { sonuca ulaşıllı ulaşıllamayacağını } \\
\text { anlayabilme }\end{array}$ & $\mathrm{f}$ & 0,0 & 0,0 & 13,3 & 9 & 16 \\
\hline $\begin{array}{l}\text { 23. Bir aracın çeşitli ölçütler } \\
\text { yönünden uygun olup olmadığını } \\
\text { belirleyebilme }\end{array}$ & $\mathrm{f}$ & 0 & 1 & 5 & 9 & 53,3 \\
\hline
\end{tabular}




\begin{tabular}{|l|l|c|c|c|c|c|}
\hline $\begin{array}{l}\text { 24. İç ölçütler açısından bir bilgi } \\
\text { bütününü değerlendirebilme }\end{array}$ & $\mathrm{f}$ & 0 & 3 & 6 & 6 & 13 \\
\hline 25. Diş ölçütler açısından bir bilgi & $\mathrm{f}$ & 0,0 & 10,0 & 20,0 & 20,0 & 43,3 \\
bütününü değerlendirebilme & $\%$ & 0,0 & 10,0 & 23,3 & 30,0 & 33,3 \\
\hline
\end{tabular}

Alan uzmanları tarafından Tablo 8'de yer alan 19. becerinin önemli olduğu görülürken; 20., 21., 22., 23., 24. ve 25. becerilerin ise çok önemli görüldüğü saptanmıştır.

Alan uzmanlarının, matematik kazanımları açısından eleştirel düşünme becerilerine verdikleri önem düzeylerine ait frekans ve yüzde değerleri Tablo 9'da verilmiştir.

Tablo 9. Alan Uzmanlarının Eleştirel Düşünme Becerilerine Matematik Kazanımları Açısından Verdikleri Önem Düzeylerine Ait Frekans ve Yüzde Değerleri

\begin{tabular}{|c|c|c|c|c|c|c|}
\hline \multirow{2}{*}{\multicolumn{2}{|c|}{ Beceriler }} & \multicolumn{5}{|c|}{ Önem Düzeyi } \\
\hline & & \multirow{2}{*}{$\begin{array}{c}\begin{array}{c}\text { Çok } \\
\text { Önemsiz }\end{array} \\
0 \\
0,0\end{array}$} & \multirow{2}{*}{$\begin{array}{c}\text { Önemsiz } \\
0 \\
0,0\end{array}$} & \multirow{2}{*}{$\begin{array}{c}\begin{array}{c}\text { Orta Düzeyde } \\
\text { Önemli }\end{array} \\
6 \\
20,0\end{array}$} & \multirow{2}{*}{$\begin{array}{c}\text { Önemli } \\
9 \\
30,0\end{array}$} & \multirow{2}{*}{$\begin{array}{c}\begin{array}{c}\text { Çok } \\
\text { Önemli }\end{array} \\
13 \\
43,3\end{array}$} \\
\hline $\begin{array}{l}\text { 26. Kıyaslama için ölçütler } \\
\text { belirleme ve kıyaslama: benzerlik } \\
\text { ve farklılıkları görme }\end{array}$ & $\begin{array}{l}\mathrm{f} \\
\%\end{array}$ & & & & & \\
\hline 27. Neden-sonuç ilişkileri kurma & $\begin{array}{l}\mathrm{f} \\
\%\end{array}$ & $\begin{array}{c}0 \\
0,0\end{array}$ & $\begin{array}{c}0 \\
0,0\end{array}$ & $\begin{array}{c}4 \\
13,3\end{array}$ & $\begin{array}{c}6 \\
20,0\end{array}$ & $\begin{array}{c}18 \\
60,0\end{array}$ \\
\hline 28. Olasılıkları düşünme & $\begin{array}{l}\mathrm{f} \\
\%\end{array}$ & $\begin{array}{c}0 \\
0,0\end{array}$ & $\begin{array}{c}2 \\
6,7\end{array}$ & $\begin{array}{c}2 \\
6,7\end{array}$ & $\begin{array}{c}7 \\
23,3\end{array}$ & $\begin{array}{c}18 \\
60,0\end{array}$ \\
\hline $\begin{array}{l}\text { 29. Bilginin geçerliğini ve } \\
\text { kaynağını sorgulama }\end{array}$ & $\begin{array}{l}\mathrm{f} \\
\%\end{array}$ & $\begin{array}{c}1 \\
3,3\end{array}$ & $\begin{array}{c}1 \\
3,3\end{array}$ & $\begin{array}{c}5 \\
16,7\end{array}$ & $\begin{array}{c}2 \\
6,7\end{array}$ & $\begin{array}{c}19 \\
63,3\end{array}$ \\
\hline $\begin{array}{l}\text { 30. Tümevarım: elde edilenlerden } \\
\text { yola çıkarak bütüncül fikirler } \\
\text { oluşurma }\end{array}$ & $\begin{array}{l}\mathrm{f} \\
\%\end{array}$ & $\begin{array}{c}0 \\
0,0\end{array}$ & $\begin{array}{c}0 \\
0,0\end{array}$ & $\begin{array}{c}3 \\
10,0\end{array}$ & $\begin{array}{c}8 \\
26,7\end{array}$ & $\begin{array}{c}17 \\
56,7\end{array}$ \\
\hline $\begin{array}{l}\text { 31. Bilgiyi farklı alanlara, } \\
\text { konulara, durumlara transfer etme }\end{array}$ & $\begin{array}{l}\mathrm{f} \\
\%\end{array}$ & $\begin{array}{c}0 \\
0,0\end{array}$ & $\begin{array}{c}0 \\
0,0\end{array}$ & $\begin{array}{c}4 \\
13,3\end{array}$ & $\begin{array}{c}5 \\
16,7\end{array}$ & $\begin{array}{c}19 \\
63,3\end{array}$ \\
\hline $\begin{array}{l}\text { 32. Paylaşımda kendini etkin bir } \\
\text { biçimde ifade edebilecek doğru dil } \\
\text { ve iletişim becerilerini kullanma }\end{array}$ & $\begin{array}{l}\mathrm{f} \\
\%\end{array}$ & $\begin{array}{c}0 \\
0,0\end{array}$ & $\begin{array}{c}2 \\
6,7\end{array}$ & $\begin{array}{c}3 \\
10,0\end{array}$ & $\begin{array}{c}11 \\
36,7\end{array}$ & $\begin{array}{c}12 \\
40,0\end{array}$ \\
\hline
\end{tabular}

Alan uzmanları tarafından Tablo 9'da yer alan eleştirel düşünme becerilerinin matematik kazanımları açısından çok önemli görüldüğü saptanmıştır.

Alan uzmanlarının, matematik kazanımları açısından yaratıcı düşünme becerilerine verdikleri önem düzeylerine ait frekans ve yüzde değerleri Tablo 10'da verilmiştir.

Tablo 10. Alan Uzmanlarının Yaratıcı Düşünme Becerilerine Matematik Kazanımları Açısından Verdikleri Önem Düzeylerine Ait Frekans ve Yüzde Değerleri

\begin{tabular}{|l|c|c|c|c|c|c|}
\hline \multirow{2}{*}{ Beceriler } & \multicolumn{3}{|l|}{ Önem Düzeyi } \\
\cline { 3 - 7 } & & $\begin{array}{c}\text { Çok } \\
\text { Önemsiz }\end{array}$ & Önemsiz & $\begin{array}{c}\text { Orta Düzeyde } \\
\text { Önemli }\end{array}$ & Önemli & $\begin{array}{c}\text { Çok } \\
\text { Önnemli }\end{array}$ \\
\hline 33. Bir sorun üzerine farklı çözüm & $\mathrm{f}$ & 1 & 1 & 4 & 8 & 16 \\
yaklaşımları getirebilme (esneklik). & $\%$ & 3,3 & 3,3 & 13,3 & 26,7 & 53,3 \\
\hline
\end{tabular}




\begin{tabular}{|c|c|c|c|c|c|c|}
\hline $\begin{array}{l}\text { 34. Hayal gücü yoluyla olayları veya } \\
\text { nesneleri zihinde canlandırma } \\
\text { (imgeleme). }\end{array}$ & $\begin{array}{l}\mathrm{f} \\
\%\end{array}$ & $\begin{array}{c}1 \\
3,3\end{array}$ & $\begin{array}{c}0 \\
0,0\end{array}$ & $\begin{array}{c}5 \\
16,7\end{array}$ & $\begin{array}{c}9 \\
30,0\end{array}$ & $\begin{array}{c}14 \\
46,7\end{array}$ \\
\hline $\begin{array}{l}\text { 35. Bir durum hakkındaki fikir ve } \\
\text { düşünceleri başka bir duruma } \\
\text { uyarlayabilme (analojik düşünme). }\end{array}$ & $\begin{array}{l}\mathrm{f} \\
\%\end{array}$ & $\begin{array}{c}0 \\
0,0\end{array}$ & $\begin{array}{c}0 \\
0,0\end{array}$ & $\begin{array}{c}6 \\
20,0\end{array}$ & $\begin{array}{c}9 \\
30,0\end{array}$ & $\begin{array}{c}14 \\
46,7\end{array}$ \\
\hline $\begin{array}{l}\text { 36. Bir şeyin yeni kullanımlarını bulma, } \\
\text { yeni anlamlar, imalar uygulama alanları } \\
\text { görme }\end{array}$ & $\begin{array}{l}\mathrm{f} \\
\%\end{array}$ & $\begin{array}{c}1 \\
3,3\end{array}$ & $\begin{array}{c}1 \\
3,3\end{array}$ & $\begin{array}{c}4 \\
13,3\end{array}$ & $\begin{array}{c}11 \\
36,7\end{array}$ & $\begin{array}{c}13 \\
43,3\end{array}$ \\
\hline $\begin{array}{l}\text { 37. Bilinen ve kabul edilenin ötesine } \\
\text { geçme }\end{array}$ & $\begin{array}{c}\mathrm{f} \\
\%\end{array}$ & $\begin{array}{c}1 \\
3,3\end{array}$ & $\begin{array}{c}0 \\
0,0\end{array}$ & $\begin{array}{c}4 \\
13,3\end{array}$ & $\begin{array}{c}8 \\
26,7\end{array}$ & $\begin{array}{c}16 \\
53,3\end{array}$ \\
\hline $\begin{array}{l}\text { 38. Yetersiz bilgiye rağmen olayları } \\
\text { kavrama }\end{array}$ & $\begin{array}{c}\mathrm{f} \\
\%\end{array}$ & $\begin{array}{c}1 \\
3,3\end{array}$ & $\begin{array}{c}2 \\
6,7\end{array}$ & $\begin{array}{c}7 \\
23,3\end{array}$ & $\begin{array}{c}9 \\
30,0\end{array}$ & $\begin{array}{c}10 \\
33,3\end{array}$ \\
\hline 39. Kendinden düşünme ve davranma & $\begin{array}{c}\mathrm{f} \\
\%\end{array}$ & $\begin{array}{c}0 \\
0,0\end{array}$ & $\begin{array}{c}1 \\
3,3\end{array}$ & $\begin{array}{c}4 \\
13,3\end{array}$ & $\begin{array}{c}6 \\
20,0\end{array}$ & $\begin{array}{c}17 \\
56,7\end{array}$ \\
\hline
\end{tabular}

Alan uzmanları tarafından Tablo 10'da yer alan yaratıcı düşünme becerilerinin matematik kazanımları açısından çok önemli görüldüğü saptanmıştır.

\section{Yorum / Tartışma}

İlgili alan yazında, daha çok Bloom taksonomisi göz önünde bulundurularak yapılmış çalışmalar yer almakta fakat üst düzey zihinsel becerilere dönük çalışmalara rastlanmamaktadır. Özellikle matematik sorularının incelenmesine dönük ülkemizde yeterli çalışma yapılmamıştır. Üst düzey zihinsel becerilerin hem matematik kazanımları açısından önem düzeyine dönük hem de matematik eğitimi alan uzmanlarının yapılan sınavlarda yer alan sorulara ilişkin görüşlerini almaya dönük bir çalışma bulunmamaktadır.

Alan uzmanlarının görüşlerine dayalı olarak ulaşılan sonuçlar geçmişte yapılan çalışmalarla (Yıldız, 1991; Eş, 2005) desteklenmekte ve günümüzde uygulanan sınavlarda üst düzey zihinsel becerilerle ilişkili daha az soru sorulmaya başlandığını göstermektedir.

Erman (2008)'ın yapmış olduğu çalışmaya paralel olarak soruların bilişsel alan basamaklarından üst düzey zihinsel becerilere yeteri kadar yer verilmediği hatta hiç yer verilmediği tespit edilmiştir. Bu durumun öğrencilerin ileriki yaşlarda devam edecekleri eğitim kurumlarına adapte olmakta ve her gün gelişmekte olan toplumumuza ayak uydurmakta zorlanacağı düşünülmektedir.

\section{Sonuçlar}

Alan uzmanlarının görüşleri dikkate alındığında 2008 SBS matematik testi sorularından hiçbiri üst düzey zihinsel becerileri ölçmemektedir. Ayrıca alan uzmanlarının kazanımlar açısından üst düzey zihinsel becerilere atfettikleri önem düzeyi oldukça yüksektir. Görüldüğü gibi alan uzmanları üst düzey zihinsel becerilerin yeterince farkındadır. Bununla birlikte öğrencilerin bir üst kurumda öğrenimlerini devam ettirmede yol almalarında önemli bir aşama olan Seviye Belirleme Sınavı soruları ise bu öneme rağmen üst düzey zihinsel becerileri ölçme açısından yetersizdir. Ülkemizin daha ileriki yıllarda öğrenme alanlarından biri olan bilişsel alanda dünya çapında kendini kanıtlayabilmesi ve daha ileri düzeyde eğitim anlayışını gerçekleştirebilmesi adına sınav sorularının incelenmesi, gerekli düzeltmelerin yapılması ve geliştirilmesi büyük önem taşımaktadır. 


\section{6. Öneriler}

Alan uzmanlarının görüşleri dikkate alınarak öğrenciler için hayati önem taşıyan sınavlarda yer alan soruların yapılandırılmasında üst düzey düşünmenin kapılarını açma ön plana alınmalıdır. Geleceğimizin garantisi olan gençler yarının düşünen ve düşündüğünü gerçekleştirebilen bireyleri olarak ülkemizi uluslararası arenada daha iyi temsil edecektir.

Yapılan ulusal sınavlardaki testlerde yer alan soruların bilişsel alanın her düzeyini ölçer nitelikte olması gerekir. Okullarda yapılan sınavlarda da bu ulusal sinavlara paralel olarak öğretmenlere destek amaçlı soru sorma sanatı konulu hizmet içi eğitimler verilmelidir.

\section{KAYNAKÇA}

Berberoğlu, G., Kaptan, F., \& Kutlu, Ö. (2002). “Türkiye Genelinde Sekizinci Sınıf Öğrencilerinin Fen Bilgisi Dersindeki Üst Düzey Zihinsel Becerilerinin İncelenmesi”. V. Ulusal Fen ve Matematik Eğitimi Kongresi. ODTÜ, Ankara.

Bloom, B. S. Ed. (1956). Taxonomy of educational objectives. The classification of educational goals. Handbook I: Cognitive domain. New York: Longmans, Gren and Company Inc.

Çevik, C. (2009). Yedinci Sınıf Seviye Belirleme Sınavı Matematik Sorularının Üst Düzey Zihinsel Becerileri Ölçme Düzeyi. Yayımlanmamış Yüksek Lisans Tezi. Abant İzzet Baysal Üniversitesi, Sosyal Bilimler Enstitüsü, Bolu.

Demirel, Ö. (2005). Eğitimde Yeni Yönelimler. Ankara: Pegema Yayıncılık.

Eş, H. (2005). Liselere Giriş Sınavları Fen Bilgisi Soruları ile İlköğretim Fen Bilgisi Dersi Sınav Sorularının Bloom Taksonomisine Göre Değerlendirilmesi. Yayınlanmamış yüksek lisans tezi. Gazi Üniversitesi, Eğitim Bilimleri Enstitüsü, Ankara.

Erman, E. (2008). 2003-2006 Yılları Arasında Yapılan Orta Öğretim Kurumlarına Öğrenci Seçme Sınavı'nda Yer Alan Tarih Bilimi Sorularının Bloom Taksonomisine Göre Değerlendirilmesi. Yayımlanmamış Yüksek Lisans Tezi. Gazi Üniversitesi, Eğitim Bilimleri Enstitüsü, Ankara.

D’Agostino, J. V. (2000). “Instructional And School Effects On Students' Longitudinal Reading and Mathematics Achievements”. School Effectiveness and School Improvement, 11 ( 2), 197-235.

Koray, C. Ö., \& Yaman, S. (2002). "Fen Bilgisi Öğretmenlerinin Soru Sorma Becerilerinin Bloom Taksonomisine Göre Değerlendirilmesi”. Gazi Üniversitesi Kastamonu Eğitim Dergisi, 10 (2), 317-324.

Krathwohl, D. R. (2002). “A Revision of Bloom's Taxonomy: An Overview”. Theory into Practice, 41 (4), 212-218.

Özçelik, D. A. (1998). Eğitim Programları ve Öğretim (Genel Öğretim Yöntemi). Ankara: ÖSYM Yayınları.

Özçelik, D. A. (1998). Ölçme ve Değerlendirme. Ankara: ÖSYM Yayınları.

Sönmez, V. (2001). Program Geliştirmede Öğretmen El Kitabı. Geliştirilmiş 9. Baskı. Ankara: Anı Yayıncllık.

Şahinel, S. (2002). Eleştirel Düşünme. Ankara: Pegema Yayıncllık.

Tan, Ş., Kayabaşı, Y., \& Erdoğan, A. (2002). Öğretimi Planlama ve Değerlendirme. Ankara: Anı Yayıncllık. Tekin, H. (2008). Eğitimde Ölçme ve Değerlendirme. Ankara: Yargı Yayınevi.

Turgut, M. F. (1986). Eğitimde Ölçme ve Değerlendirme Metotları. Ankara: Saydam Matbaası.

Yıldız, N. (1991). 1989 Yılı Fen Lisesi Giriş Sınavı Sorularının Psikometrik Özelliklerinin İncelenmesi. Yayınlanmış Yüksek Lisans Tezi. Hacettepe Üniversitesi, Sosyal Bilimler Enstitüsü, Ankara.

Yüksel, S. (2007). "Bilişsel Alanın Sınıflamasında (Taksonomi) Yeni Gelişmeler ve Sınıflamalar”. Türk Eğitim Bilimleri Dergisi, 5 (3), 479-509. 